\title{
Preloading system with partially penetrating vertical drains in marine soft clays in Egypt: 2D and 3D comparative FE study
}

\author{
Ahmed M. Abouhashem ${ }^{1 *}$, Alaa El-Din A. El-Gendy ${ }^{2}$, Mohamed H. Rabie ${ }^{3}$, Mohamed A. Mostafa \\ ${ }^{1 *}$ Department of Geotechnical Engineering, Helwan University, Cairo, EGYPT \\ ${ }^{2}$ Department of Geotechnical Engineering, Helwan University, Cairo, EGYPT \\ ${ }^{3}$ Department of Geotechnical Engineering, Helwan University, Cairo, EGYPT \\ ${ }^{4}$ Department of Geotechnical Engineering, Helwan University, Cairo, EGYPT \\ *Corresponding Author: e-mail: ahmed.abouhashem@yahoo.com, Tel +2012 05058650 \\ ORCID iDs: https://orcid.org/0000-0003-1111-2430 (Ahmed), https://orcid.org/0000-0002-3192-3065 (Alaa), https://orcid.org/0000-0003-0629-4102 (Mohamed \\ Rabie), https://orcid.org/0000-0003-2136-130X (Mohamed)
}

\begin{abstract}
A large-scale trial embankment provided with partially penetrating prefabricated vertical drains (PVD) was installed in consolidating marine clay deposits at East-Port said industrial zone project in Egypt. The trial embankment was constructed with a bottom area of $150 \times 150 \mathrm{~m}$ and a height of $5.5 \mathrm{~m}$ to evaluate the efficiency of the improvement system and verify the design parameters. An intensive instrumentation system was built-up including shallow settlement indicators, vibrating wire piezometers, extensometer, and inclinometers. Two and three-dimensional finite element analyses (FE) were performed to study the effect of the preloading system provided with partially PVD in consolidating marine clay deposits. FE models were validated and showed good agreement with the field observations in terms of vertical displacement of embankment center, and lateral soil deformation beneath the embankment toe.
\end{abstract}

Keywords: 2D, 3D, Finite element, Embankment Instrumentation, Marine soft clay, Prefabricated vertical drains (PVD).

DOI: http://dx.doi.org/10.4314/ijest.v13i3.2

Cite this article as:

Abouhashem A.M., El-Gendy A.E.A., Rabie M.H., Mostafa M.A. 2021. Preloading system with partially penetrating vertical drains in marine soft clays in Egypt: 2D and 3D comparative FE study. International Journal of Engineering, Science and Technology, Vol. 13, No. 3, pp. 10-22. doi: 10.4314/ijest.v13i3.2

Received: August 15, 2021; Accepted: August 24, 2021; Final acceptance in revised form: September 2, 2021

\section{Introduction}

Many coastal regions worldwide contain very soft deposits that have unfavorable geotechnical properties. One of these areas is East-Port said which is located in the northeast sector of Egypt and widely known for soft soil deposits encountered along the Mediterranean coast. The soil formation within this area provides a geotechnical challenge due to the existence of soft soil deposits that have thicknesses over $40.0 \mathrm{~m}$. These deposits are normally characterized by low shear strength and high compressibility characteristics which make them a difficult engineering exercise. Many improvement techniques are used to mitigate unacceptable total and differential settlements of underlying soft soil (Indraratna et al., 2005) such as Vibro-replacement, electro-osmotic, and deep mixing but the associated cost may become excessive when the soft deposits layer extends to lower depths. Indeed, the low vertical permeability of the soft clay deposits requires a too long time to achieve the target settlement compared to the available construction period. Furthermore, the horizontal permeability of these deposits is much higher than its vertical permeability. Thus, using vertical drains in soft soils deposits reduces the drainage path from the total thickness of the soil layer (in case of vertical consolidation) to the half of the drain spacing (in case of horizontal consolidation) (Indraratna et al., $2012 \& 2015$ ). 
Preloading system provided with partially penetrating prefabricated vertical drains (PVDs) is one of the effective techniques used effectively to reduce the post-construction settlement, mitigate the effects of differential settlement on structures, and increase the shear strength of the soft soil deposits as well. In this method, a surcharge load, usually in the form of an embankment that is equal to or greater than the anticipated foundation stress, is applied to the soft soil layer until most of the primary consolidation has been achieved. Indraratna et al. (2005) stated that vertical drains combined with pre-loading are amongst the most effective techniques known for accelerating consolidation and stabilizing ground. Vertical drains reduce the drainage path and accelerate the dissipation of excess porewater pressure generated from the application of surcharge loads. This paper uses the trial embankment vertical and lateral displacement records to compare the accuracy and appropriateness of predictions made using two and three-dimensional finite element analysis.

\section{Ground condition and trial field zone}

2.1 Site topography: The site topography comprises a relatively flat area with an average elevation of around +0.5 meters above mean sea level. To establish a stable working platform, the entire construction area was reclaimed with a sand blanket up to an elevation of +1.00 meters above mean sea level. the subsurface condition in the site area can be classified mainly into five distinct soil layers, as shown in (Figure 1): on top is $1.0 \mathrm{~m}$ fill layer (sand blanket) followed by $15 \mathrm{~m}$ of soft silty clay with interlayers of silty sand followed by $30 \mathrm{~m}$ layer of very soft clay to stiff clay layer, which is underlain by a dense to very dense sand layer followed by stiff to hard clay layer. The ground-water table is located close to the ground surface.
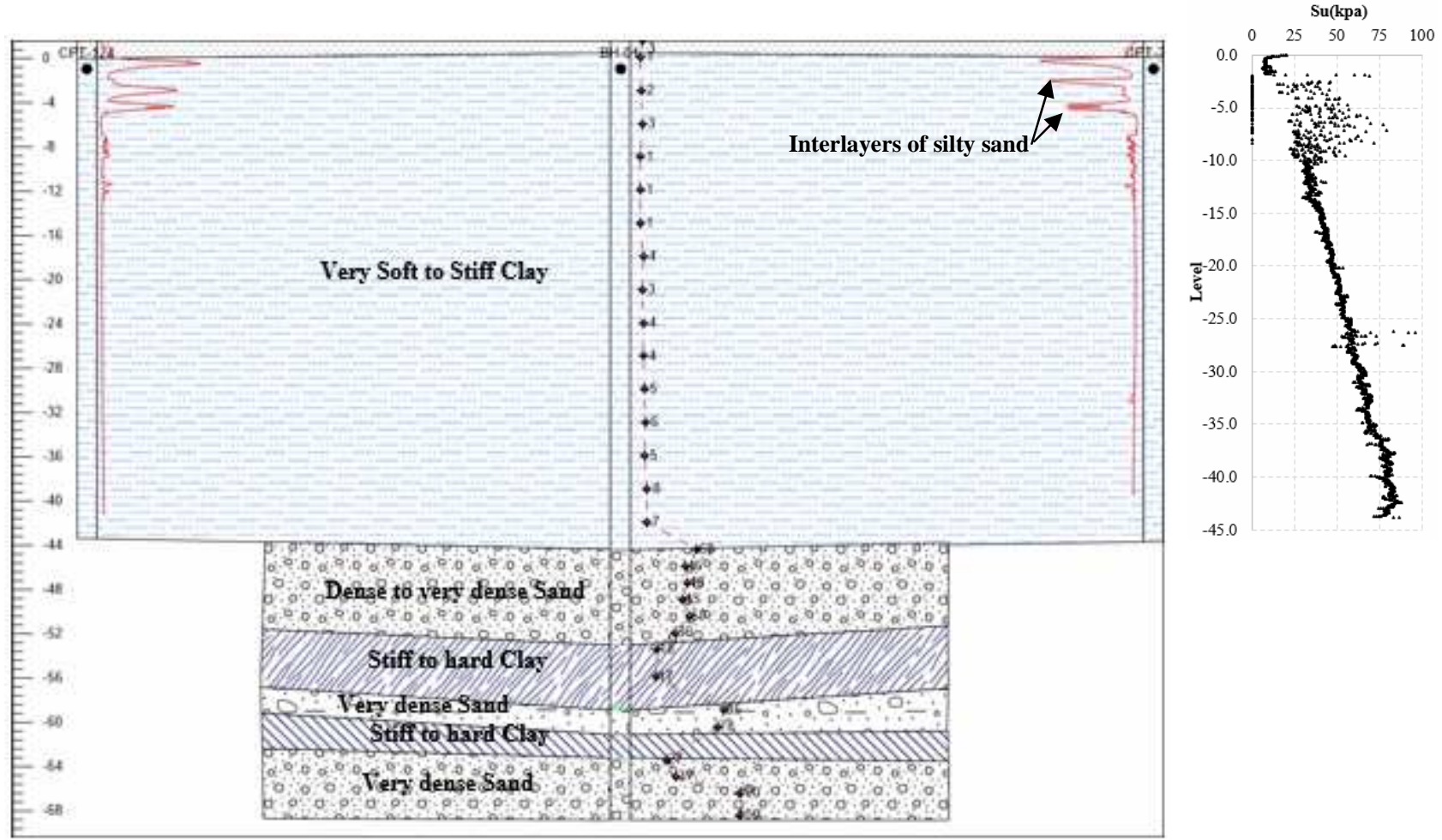

Figure 1. Subsoil stratigraphy

2.2 Trial Embankment: A large-scale trial field zone (trial embankment) was constructed with a bottom area of $150 \times 150 \mathrm{~m}$ and a height of $5.5 \mathrm{~m}$. Vertical drains with an average width of $100 \mathrm{~mm}$ and thickness of $4 \mathrm{~mm}$ were installed from the fill top layer down to a depth of $25.0 \mathrm{~m}$ and arranged in a triangular pattern with a spacing of $1.50 \mathrm{~m}$. The embankment was constructed using a sand fill with an average density of $17 \mathrm{kN} / \mathrm{m}^{3}$. Settlement plates, inclinometers, extensometers were installed beneath the embankment to measure settlement, lateral displacement and, pore water pressures. The sequence of erection for instrumentation points had in carried out in the arrangement shown in (Figure 2) while (Figure 3) shows the trial embankment and the monitoring system arrangement.

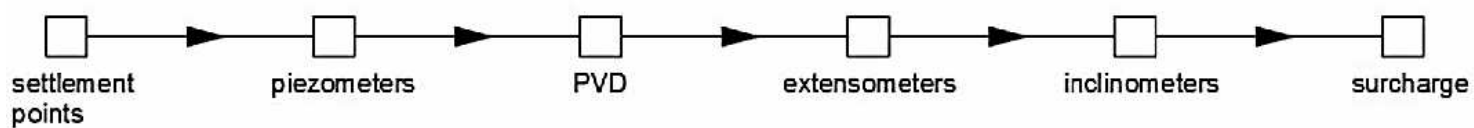

Figure 2. Sequence of erection for instrumentation points (Keller Holding GmbH) 
The trial zone filling process was carried out for 50 days while the instruments were installed immediately after installation of the vertical drains and the measurements continued for 450 days. The surcharge history and the correspondent vertical displacements for the trial embankment center is shown in (Figure 4) while (Figure 5) shows the variation of vertical displacement and lateral displacement for the trial zone center and toe. These figures show that after 450 days of surcharge loading, the vertical displacement of the embankment ranges between $180 \mathrm{~cm}$ to $215 \mathrm{~cm}$ with an average value of $198 \mathrm{~cm}$ while the lateral displacement reached to $16 \mathrm{~cm}$.

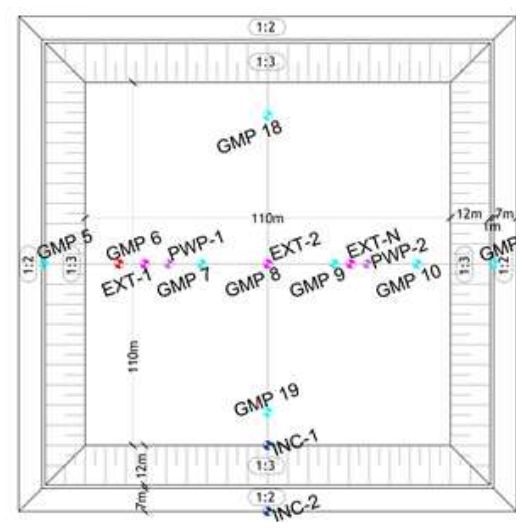

(a)

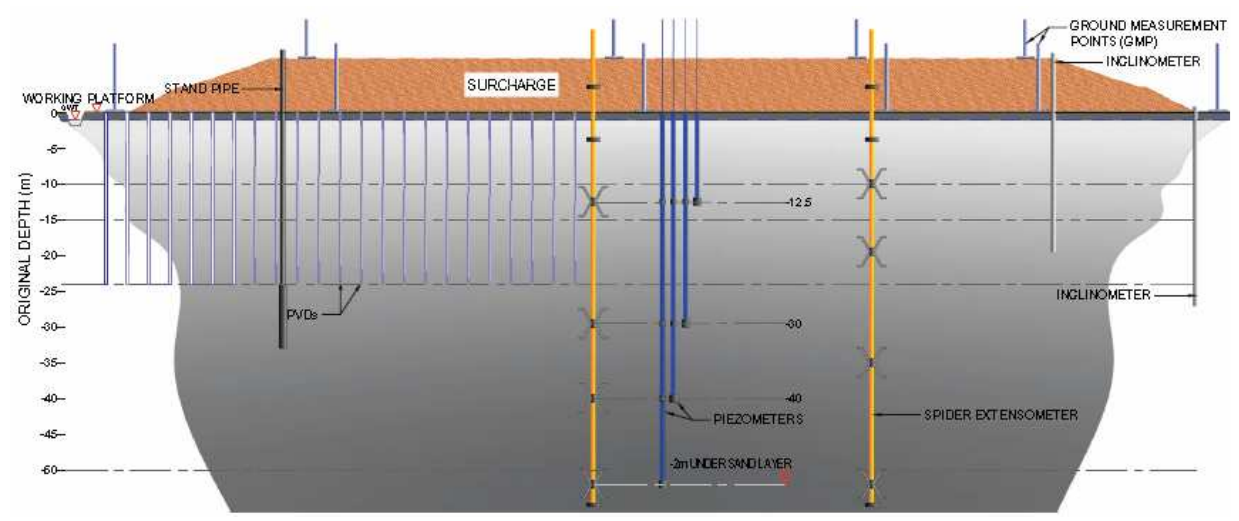

(b)

Figure 3. Trial embankment and location of the monitoring system (a) Layout (b) Cross-section (Keller Holding GmbH)

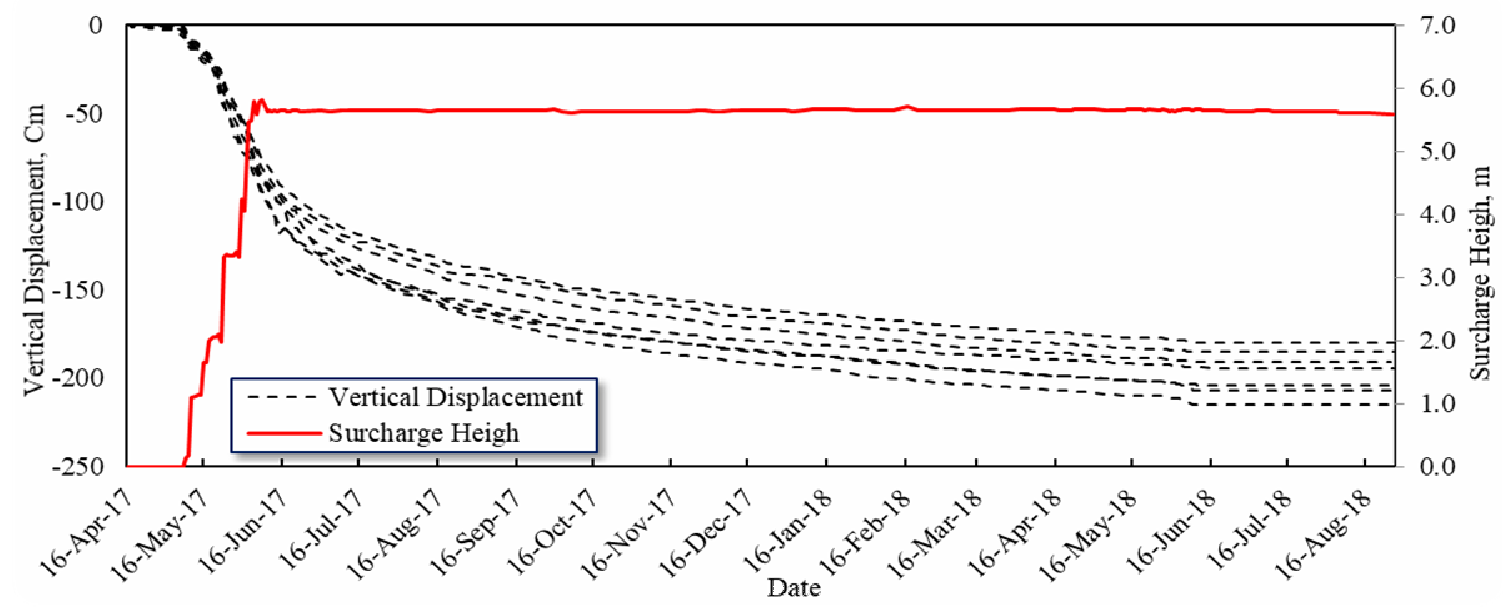

Figure 4. Surcharge history and the correspondent vertical displacements for the trial embankment for all measuring points 


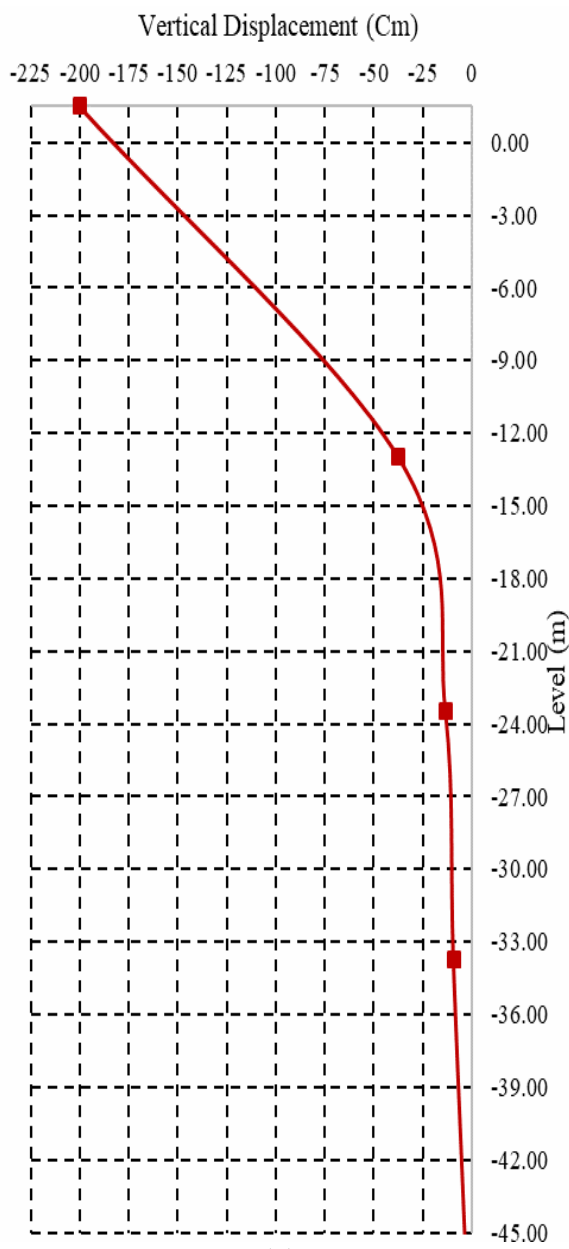

(a)

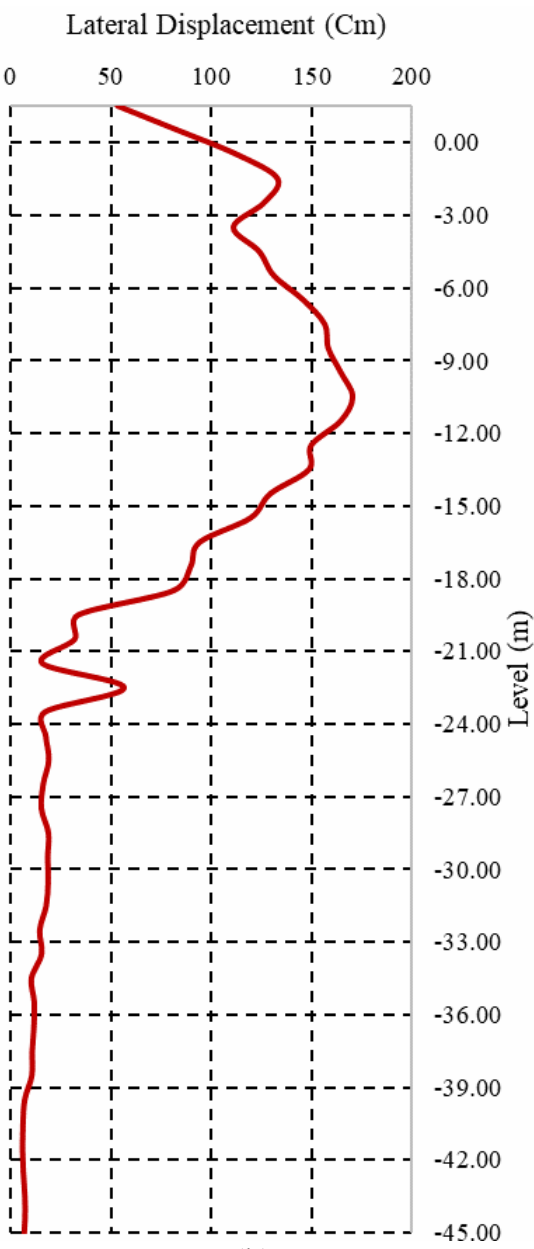

(b)

Figure 5. Variation of displacement with level (a) vertical displacement for embankment center (b) lateral displacement for embankment toe

\section{Verification and selection of analysis parameters}

3.1 Coefficient of horizontal permeability: By considering the methods for evaluating the coefficient of horizontal permeability $\left(\mathrm{K}_{\mathrm{h}}\right)$ introduced by Jamiolkowski et al. (1985), Parez \&Fauriel (1988); Houlsby and Teh's (1988), (Figure 6) shows the variation of the coefficient of horizontal permeability with level for all used methods. From this figure, the design value can be taken as 0.015 $\mathrm{m} /$ year down to level -7.50 followed by $0.04 \mathrm{~m} /$ year down to level -15.00 followed by $0.01 \mathrm{~m} /$ year for the rest of the layer.

3.2 Coefficient of horizontal permeability: The soil permeability changes during the consolidation analysis according to the following relationship as stated by Taylor (1948):

$$
\log \left(\frac{k}{k_{0}}\right)=\frac{\Delta e}{c_{k}}
$$

In practice, $C_{c} / C_{k}$ ranges between 0.5 and 2.0 (Berry and Wilkinson, 1969; Mesri and Rokhsar, 1974), with $C_{k}$ taken from the empirical relation $C_{k}=0.5 e_{0}$ while Tavenas et al. (1983) defined it as the slope of the void ratio vs log k. the effect of permeability change index $C_{k}$ had been investigated on the vertical displacement using PLAXIS 2D with a different value of $C_{k}$ as follows:

$$
\begin{aligned}
c_{k} & \approx 0.5 e_{0} \mathrm{ss} \\
C_{c} / C_{k} & =0.5 \sim 10.0 \mathrm{ss}
\end{aligned}
$$

The results of the study are shown in (Figure 7) which clearly prove that permeability change index $\mathrm{C}_{\mathrm{k}}$ with value higher than $\mathrm{C}_{\mathrm{k}}=3 \mathrm{C}_{\mathrm{c}}$ has a minor effect on the final displacement value. 


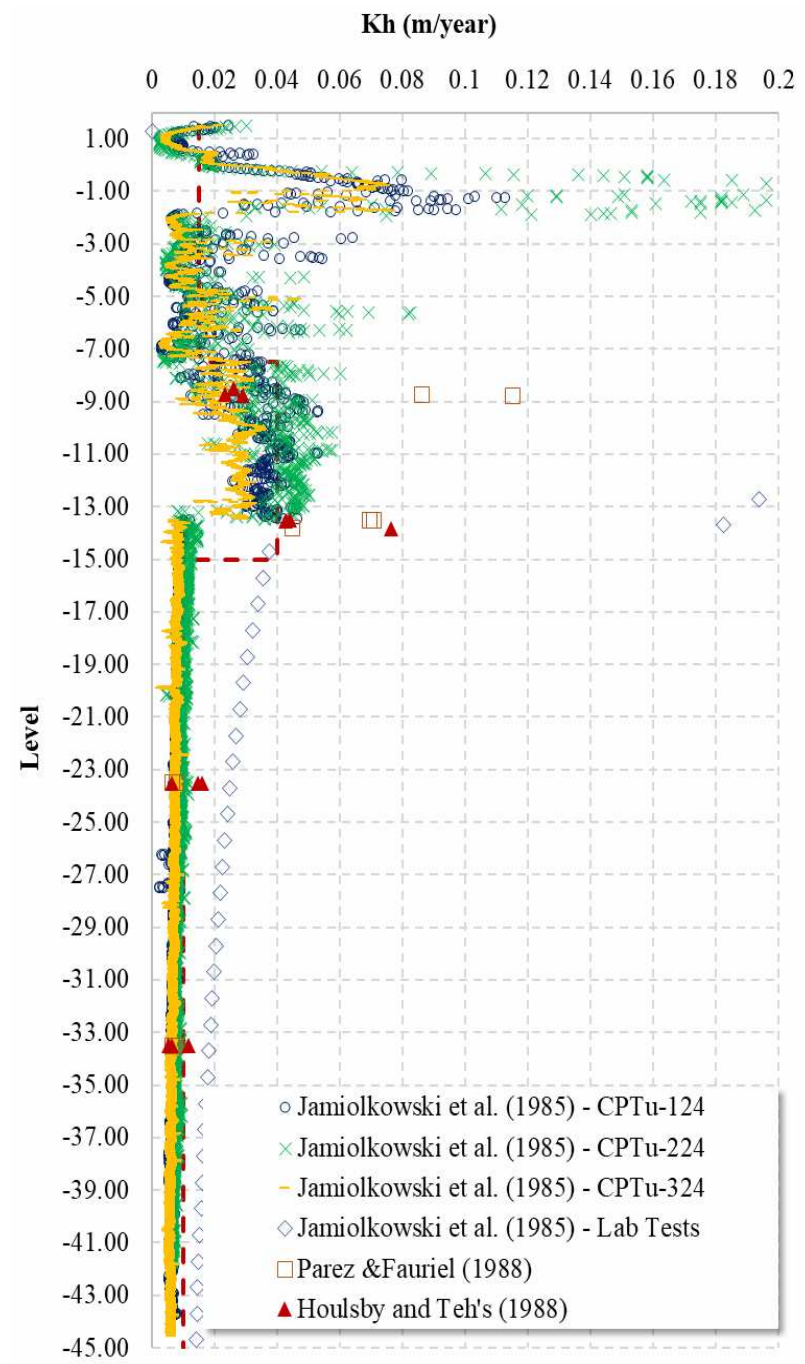

Figure 6. Variation of coefficient of horizontal permeability $\left(\mathrm{K}_{\mathrm{h}}\right)$ with level

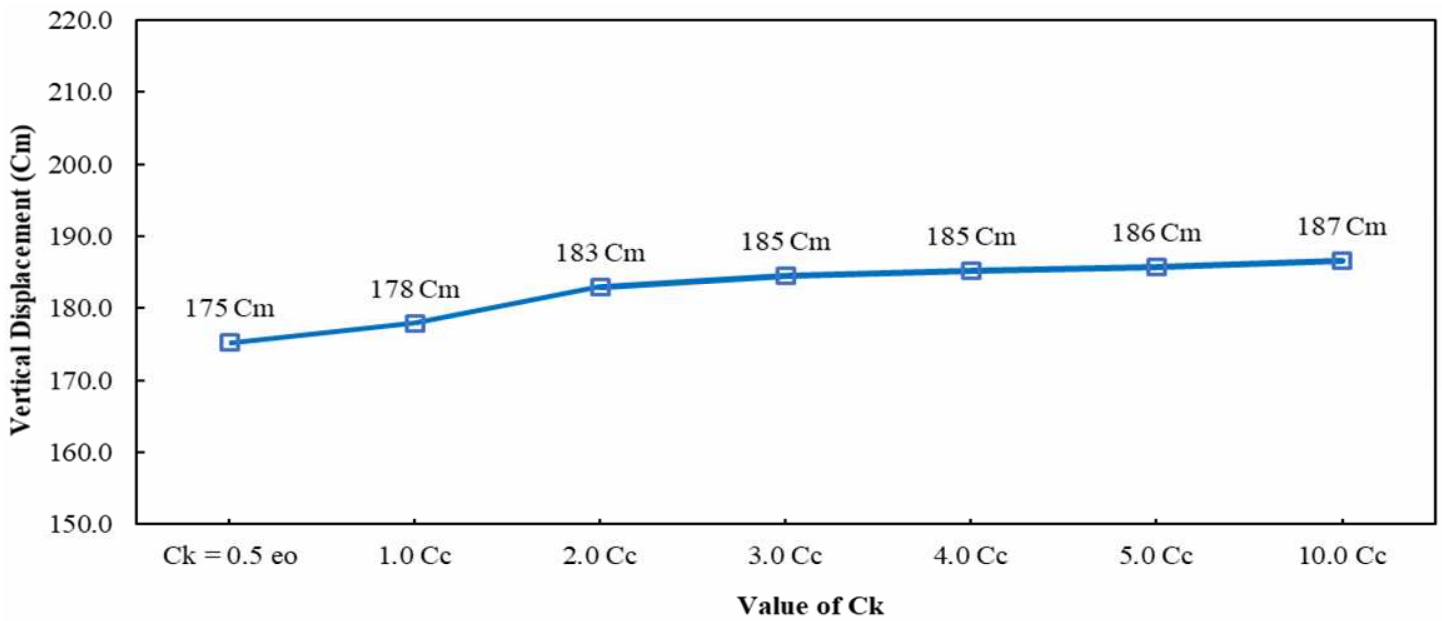

Figure 7: Total vertical displacement for all studied cases

3.3 Consolidation parameters: The consolidation parameters $\left(\mathrm{C}_{\mathrm{c}}, \mathrm{C}_{\mathrm{r}}, \mathrm{e}_{\mathrm{o}}, \mathrm{OCR}\right)$ used to calculate soft soil model parameters and concluded from the laboratory odometer tests had been verified using lab-test module included in PLAXIS software considering the following steps: 
- The stress-strain curve had been concluded from the PLAXIS software for the case of odometer test. The results of the analysis are shown in (Figure 8).

- Using PLAXIS Stress-strain relationship, the equivalent Stress-void ratio relationship had been concluded by estimating the void ratio from the relation:

$$
e=\varepsilon\left(1+e_{0}\right)+e_{0}
$$

- $\quad$ Finally, the Stress-void ratio relationship concluded from the PLAXIS lab-test module had been compared to the actual laboratory oedometer results as shown in (Figure 9). The analysis results show close agreement between the concluded stress-strain curves from PLAXIS and laboratory odometer test results.

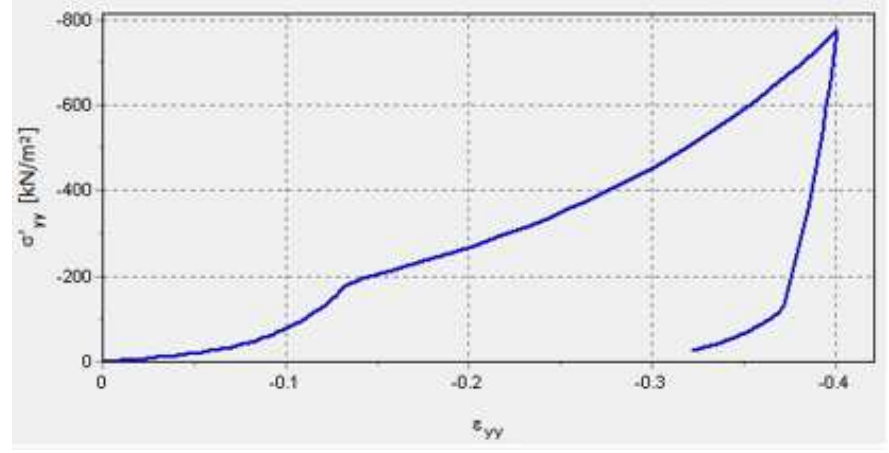

Depth $15.5 \mathrm{~m}$

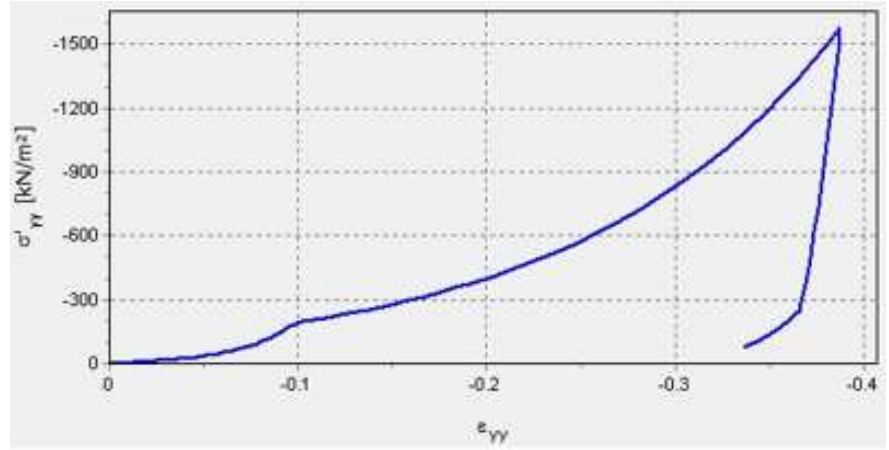

Depth 36.0m

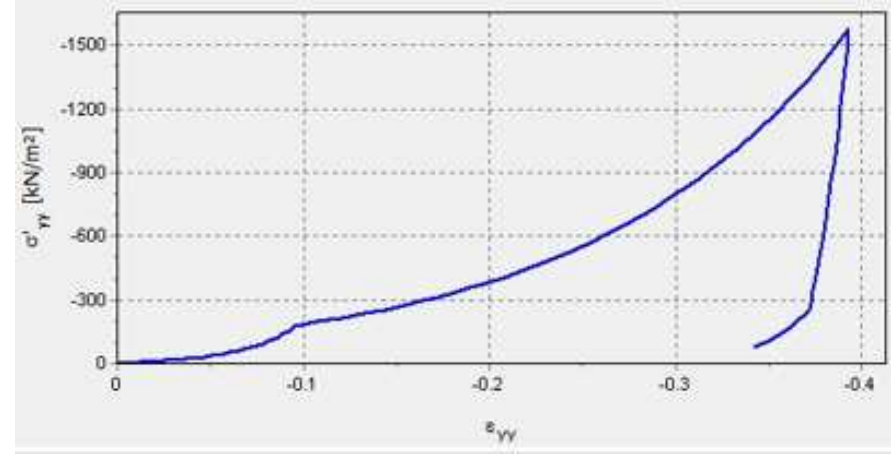

Depth $25.5 \mathrm{~m}$

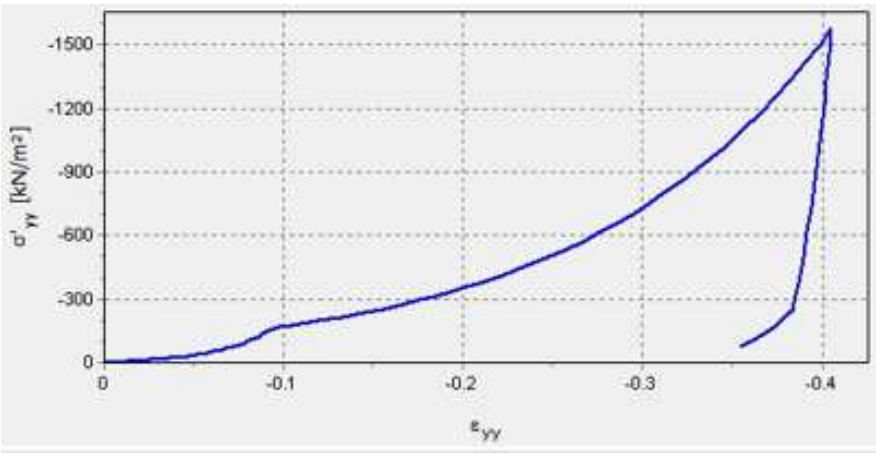

Depth $44.5 \mathrm{~m}$

Figure 8. Stress-strain curve as concluded from PLAXIS analysis 

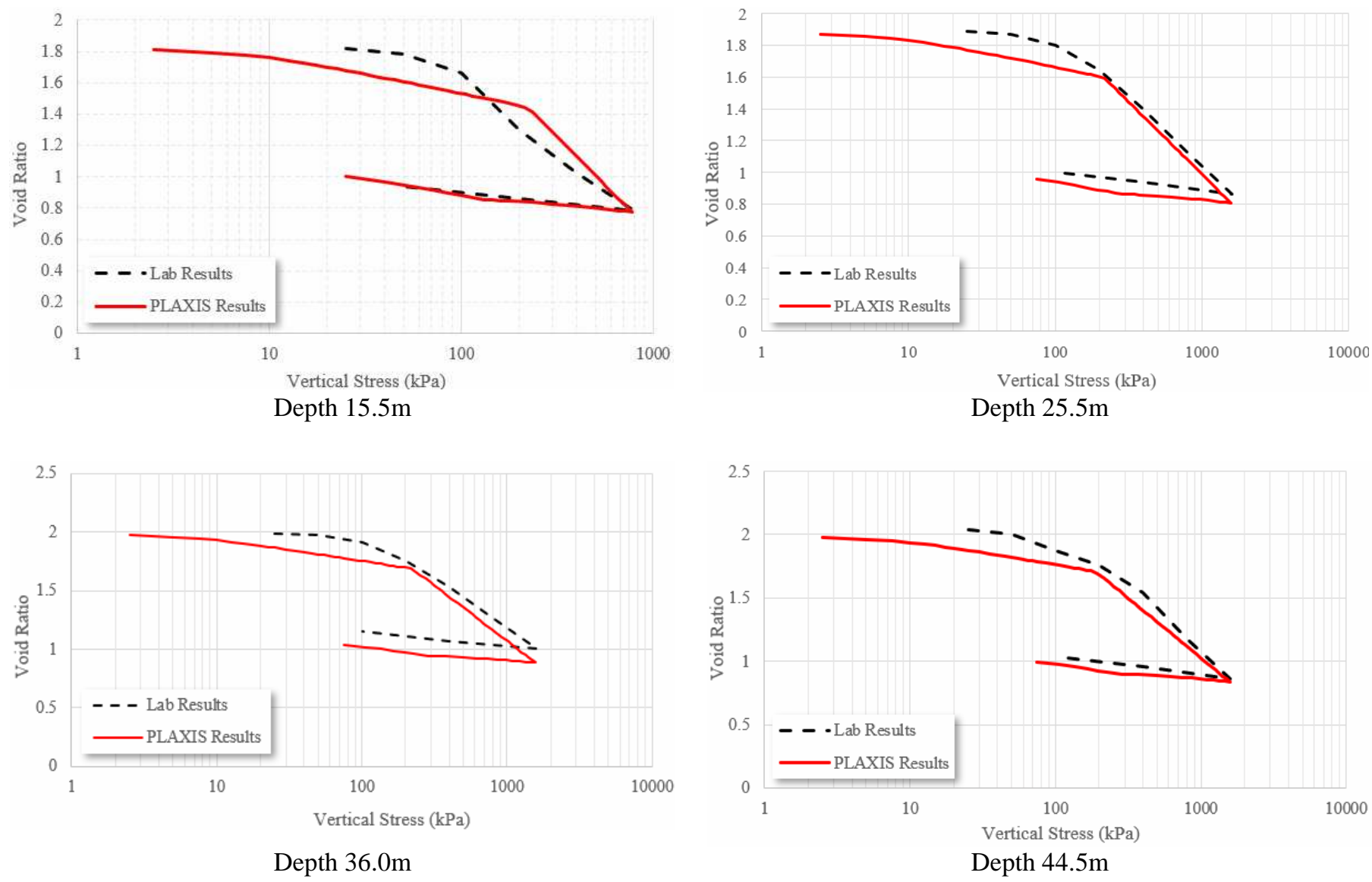

Depth $36.0 \mathrm{~m}$

Depth $44.5 \mathrm{~m}$

Figure 9. PLAXIS soil test results using SSM with respect to laboratory odometer test results

\section{Numerical modeling}

Two and three-dimensional Numerical models using the finite element-based software PLAXIS 2020 were generated to analyze the case under study. The plain-strain analysis was chosen for two-dimensional modelling to simulate the half of the embankment with a total number of elements (15-noded triangles) in this model is 1343. For the soil models used in this study, the fill surcharge was modelled using the Mohr-Coulomb model (MC) while the clay layers were modelled using the soft Soil model (SSM). (Table 1) summarizes the geotechnical parameters used in the finite element analysis.

Table 1. Geotechnical parameters for finite element modelling

\begin{tabular}{|c|c|c|c|c|c|c|c|c|c|}
\hline \multirow{2}{*}{ Layer Description } & \multirow{2}{*}{$\begin{array}{c}\text { Soil } \\
\text { Model }\end{array}$} & \multirow{2}{*}{$\boldsymbol{\Phi}$} & \multicolumn{3}{|c|}{ Consolidation Parameters } & \multicolumn{3}{|c|}{$\begin{array}{c}\text { Time-Settlement } \\
\text { Parameters }\end{array}$} \\
\cline { 5 - 11 } & & & $\mathbf{C}_{\mathbf{c}}$ & $\mathbf{C}_{\mathbf{r}}$ & $\mathbf{e}_{\mathbf{o}}$ & $\mathbf{O C R}$ & $\begin{array}{c}\mathbf{K}_{\mathbf{h}} \\
(\mathbf{m} / \mathbf{y})\end{array}$ & $\begin{array}{c}\mathbf{K}_{\mathbf{v}} \\
(\mathbf{m} / \mathbf{y})\end{array}$ & $* \mathbf{C}_{\mathbf{k}}$ \\
\hline Platform/Embankment Fill & $\mathrm{MC}$ & $36^{\circ}$ & -- & -- & -- & -- & 365 & 365 & -- \\
\hline $\begin{array}{c}\text { Silty Clay/Clayey Silt with } \\
\text { interlayers of Sand }\end{array}$ & $\mathrm{SSM}$ & $26^{\circ}$ & 1.2 & 0.12 & 1.80 & 2.25 & 0.015 & 0.0015 & 2.4 \\
\cline { 4 - 11 } & $\mathrm{SSM}$ & $26^{\circ}$ & 1.2 & 0.12 & 1.80 & 1.10 & 0.04 & 0.004 & 2.4 \\
\hline Silty Clay & $\mathrm{SSM}$ & $26^{\circ}$ & 0.9 & 0.09 & 1.90 & 1.10 & 0.01 & 0.0033 & 1.8 \\
\hline
\end{tabular}

* Permeability change index $\mathrm{C}_{\mathrm{k}}$ had been selected as $2 \mathrm{Cc}$ as per recommended Berry and Wilkinson (1969).

The soil parameter for the soft soil model (SSM) includes the modified compression index $\lambda^{*}$ and the modified swelling index $\kappa^{*}$ which are defined in (PLAXIS user's manual) as: 


$$
\begin{aligned}
\lambda^{*} & =\frac{C_{c}}{2.303\left(1+e_{0}\right)} \\
\kappa^{*} & =\frac{2 C_{r}}{2.303\left(1+e_{0}\right)}
\end{aligned}
$$

4.1 Model dimensions: To accurately compare the behavior of trial field embankment records with the finite element results, a sensitivity analysis had been performed to select the appropriate location for the model rigid boundary after the embankment slope toe. The sensitivity analysis had studied different locations of the model boundary as a function of the surcharge fill height $(\mathrm{H})$. The study had been carried out using both $2 \mathrm{D}$ and $3 \mathrm{~d}$ analysis considering a rigid boundary located at distance $(\mathrm{X})$ varies between $(1 \mathrm{H}$ to $20 \mathrm{H}$ ). the results of the analysis are presented in (Figure 10) and showed that the location of the FE boundary has a minor effect on the final lateral displacement starting from a distance of 13 times the embankment height $(>65 \mathrm{~m})$. Accordingly, the rigid boundary limit had been selected at a distance of $75 \mathrm{~m}$ from the embankment toe.

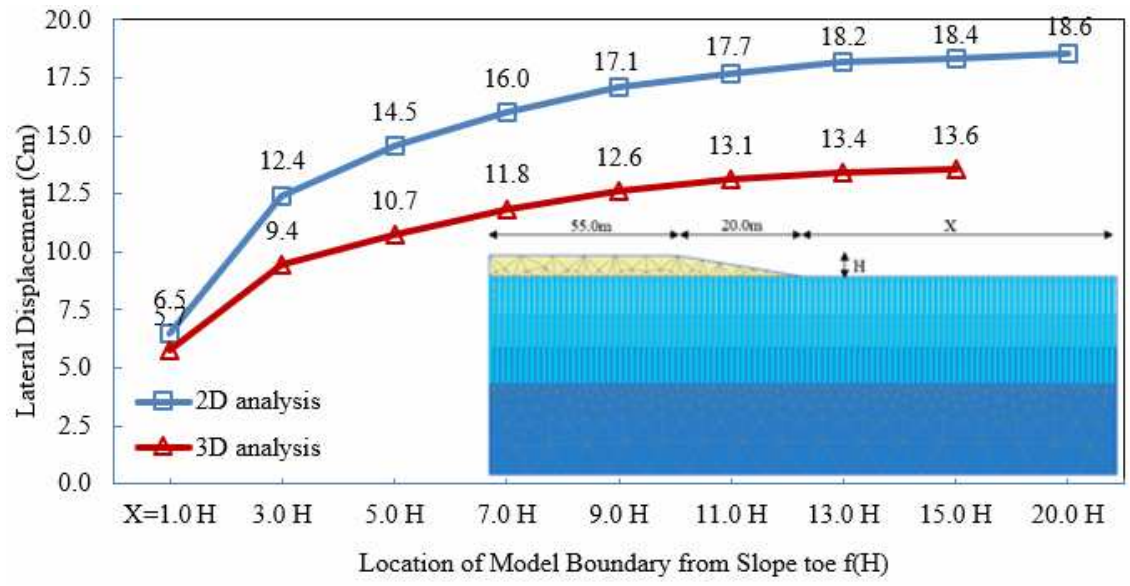

Figure 10. Effect of Location of Model Boundary from Slope toe on the lateral displacement

For 3D analysis, and considering the large area of the trial field embankment (top area $110 \mathrm{~m} x 110 \mathrm{~m}$ and bottom area of $150 \mathrm{~m} x$ $150 \mathrm{~m}$ ), modelling the entire embankment requires a huge number of elements that can exceed the available current computer capacities. To cover this problem, 3D FE analysis had been performed considering minimizing the model dimensions by modelling a portion of the embankment only with a dimension of $25 \mathrm{~m} \times 150 \mathrm{~m}$ with adjusting the boundaries deformation and groundwater flow conditions at symmetry edges. (Figure 11) shows the selected 3D model dimensions compared to actual dimensions while (Figure 12) shows the geometry of the finite element models used in the analysis.

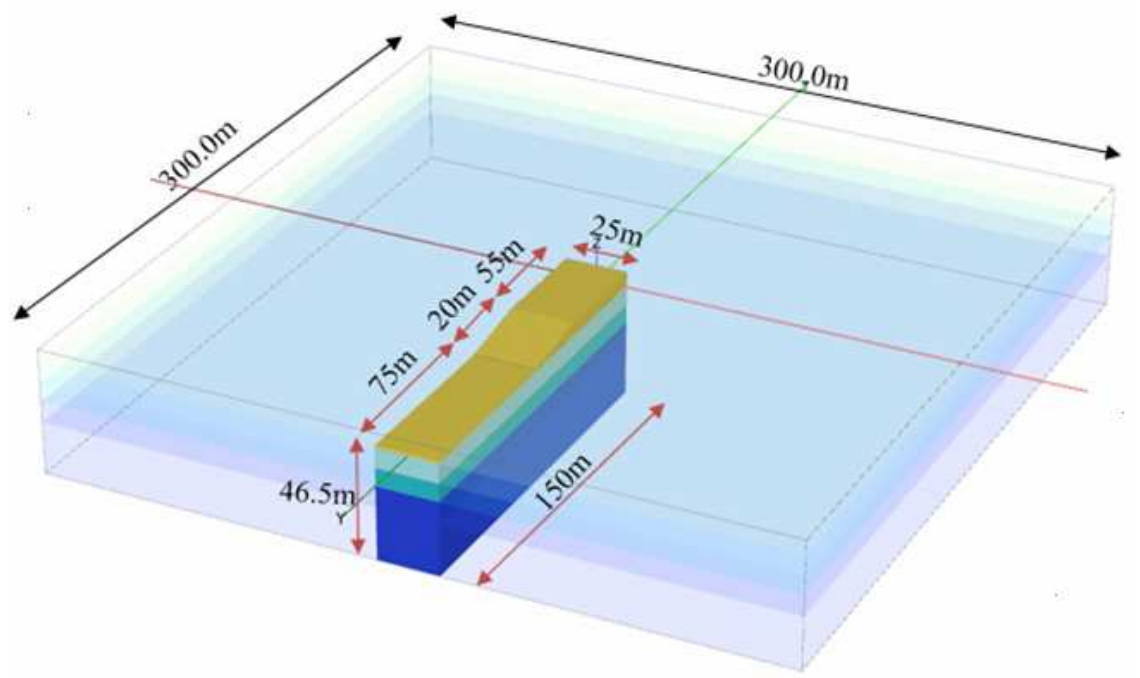

Figure 11. Selected 3D model dimensions compared to actual dimensions 


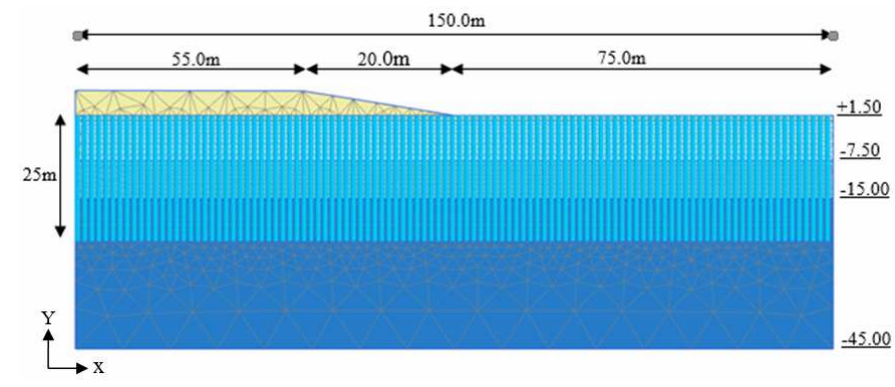

(a)

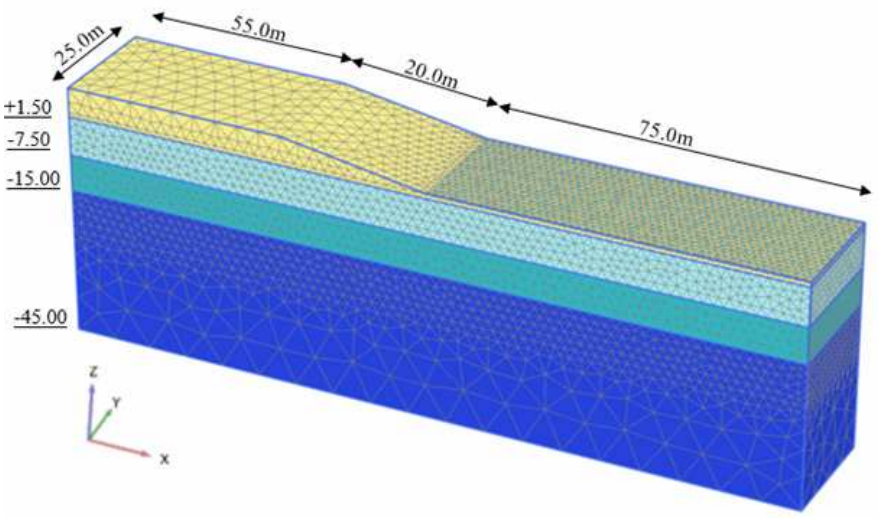

(b)

Figure 12. PLAXIS model geometry considered in the study (a) 2D (b) 3D

For simulation of the vertical drains in the two dimensional plain-strain analysis, the equivalence between axisymmetric and plane strain conditions prior to finite element modeling has been performed based on the permeability equivalency procedure proposed by Hird et al. (1995) For ideal drains as expressed in the following equation:

$$
\frac{k_{h p}}{k_{a x}}=\frac{0.67}{[\ln (n)-0.75]}
$$

Where, $\mathrm{k}_{\mathrm{hp}}$ is the horizontal permeability of in plane strain unit cell, $\mathrm{k}_{\mathrm{ax}}$ is the horizontal permeability in axisymmetric unit cell, $\mathrm{n}$ is the influence ratio $\mathrm{r}_{\mathrm{e}} / \mathrm{r}_{\mathrm{w}}$.

For vertical drains pattern simulation, an equivalent rectangular spacing had been considered with same drain influence ratio (n) for triangular pattern.

\section{Results Analysis}

The results of PLAXIS analysis show that the vertical displacement at embankment center after 450 days from end of backfill process at level +1.50 is about $1.83 \mathrm{~m}$ and $1.97 \mathrm{~m}$ for the $2 \mathrm{D}$ and $3 \mathrm{D}$ analysis respectively. (Figure 13) shows the time-settlement relationship concluded from the FE analysis. While (Figure 14) shows the variation of vertical displacement with level.

For lateral displacement, the results of PLAXIS analysis show that the lateral displacement at embankment slope toe after 450 days from end of backfill process is about $18 \mathrm{~cm}$ and $14 \mathrm{~cm}$ for the 2D and 3D analysis respectively. (Figure 15) shows the variation of lateral displacement with level.

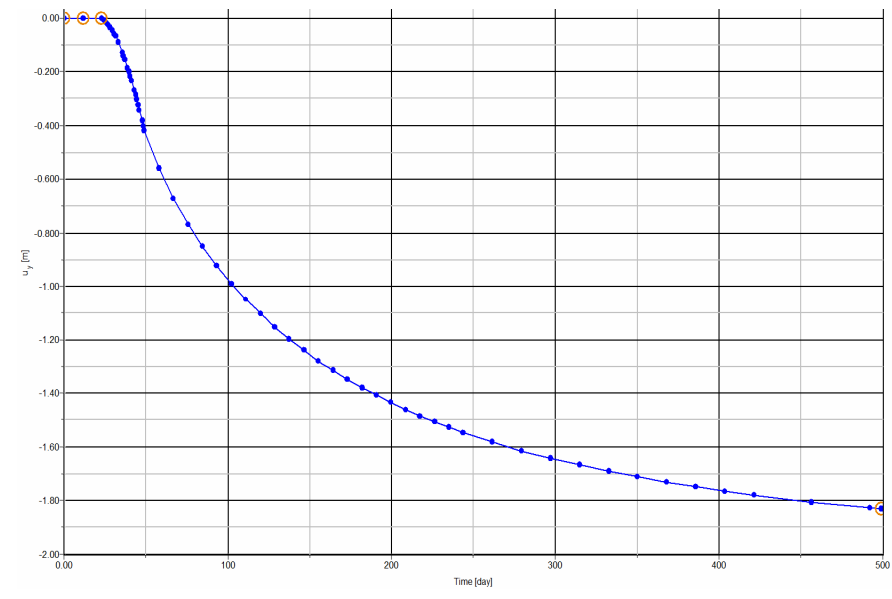

(a) 2D analysis

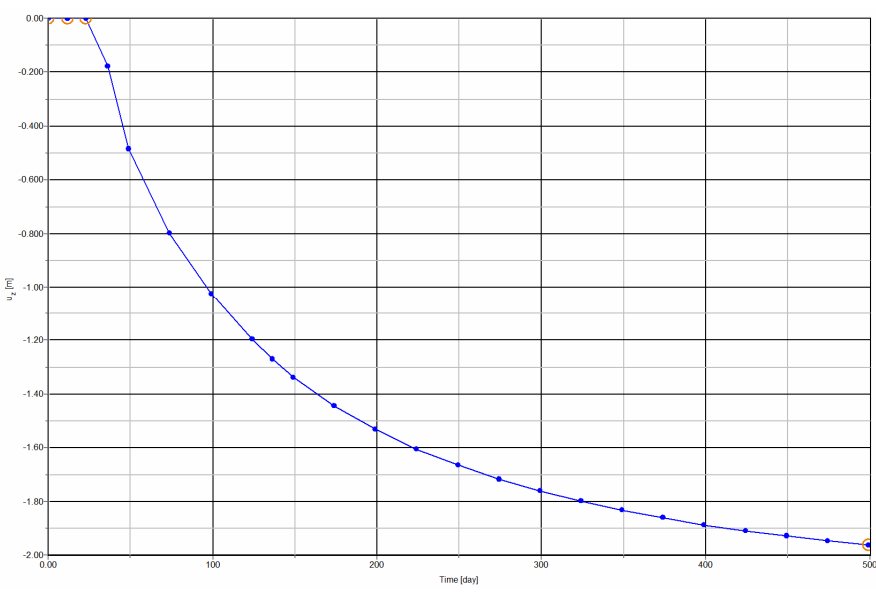

(b) $3 \mathrm{D}$ analysis

Figure 13. Time-settlement relationship concluded from FE analysis for embankment center after 450 days from end of backfill process 


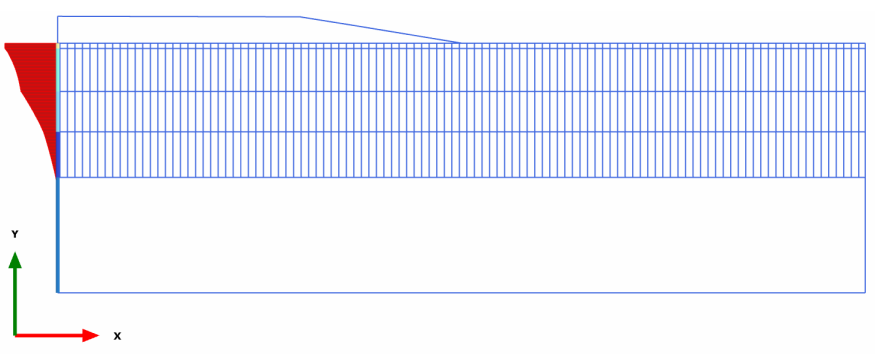

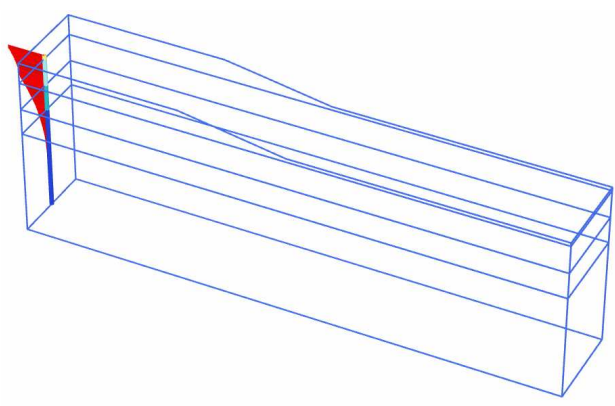

(a) 2D analysis

(b) $3 \mathrm{D}$ analysis

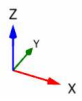

Figure 14. Vertical displacement versus level as resulted from FE analysis after 450 days from end of backfill process

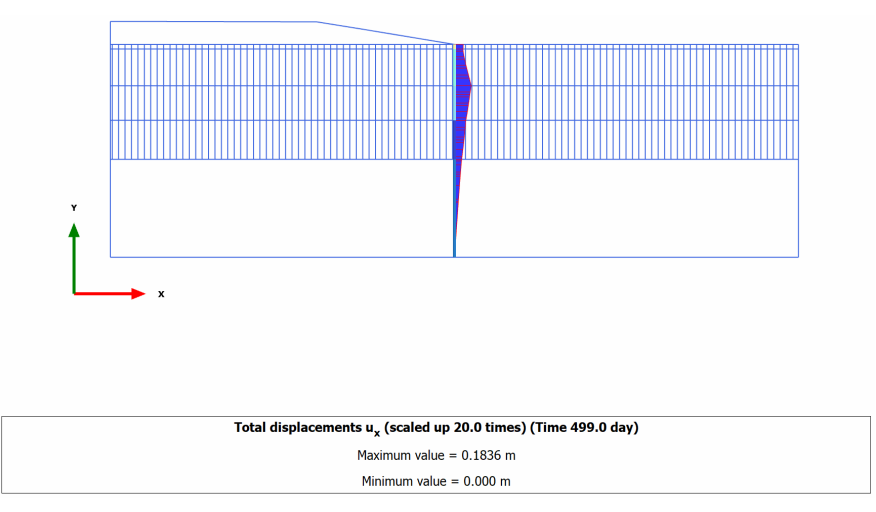

(a) $2 \mathrm{D}$ analysis

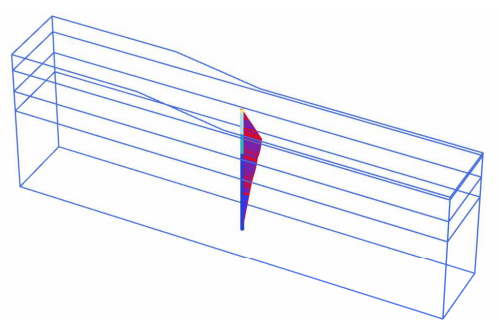

$\sum^{2}$

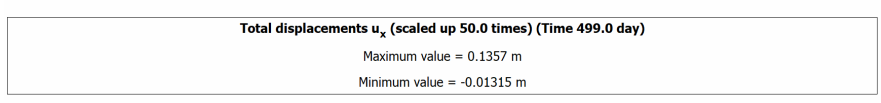

(b) $3 \mathrm{D}$ analysis

Figure 15. Lateral displacement versus level concluded from FE analysis for embankment slope toe after 450 days from end of backfill process

Based on the FE analysis and with respect to the trial embankment field vertical displacement measurements (Figure 16), it is clear that 2D analysis is generally underestimated the vertical displacement during the consolidation time. Considering the average measured vertical displacement of $198 \mathrm{~cm}$, the average ratio of $2 \mathrm{D} \mathrm{FE}$ analysis to the in-situ vertical displacement is about 1.08 . For 3D model, the results of analysis show a good agreement with the filed records with an average ratio of 1.0 to the in-situ vertical displacement. For the first 200 days from the end of the backfill process, the field measurements show higher vertical displacement values in this period compared to the finite element results with difference percentage reached about $25 \%$ probably due to the presence of Sand interlayers in the upper $15 \mathrm{~m}$ that might affect significantly and accelerated the settlement.

With respect to the vertical displacement variation with depth, (Figure 17a) shows the vertical displacement variation with time resulted from the numerical analysis with respect to field measurements. From this figure, both 2D and 3D analysis show good agreement with the filed records in all measured levels. Only for measuring station at level -13.00, PLAXIS analyses overestimated the displacement value and showed higher value with a difference percentage of about $65 \%$ and $85 \%$ in the $2 \mathrm{D}$ and $3 \mathrm{D}$ analysis respectively.

For lateral measurements, (Figure 17b) shows the lateral displacement variation with time resulted from the numerical analysis with respect to field measurements. From this figure, it's clear that $2 \mathrm{D}$ analysis is close to the field measured value with a difference percentage of about $6 \%$ while 3D analysis shows a difference percentage of about $20 \%$. 


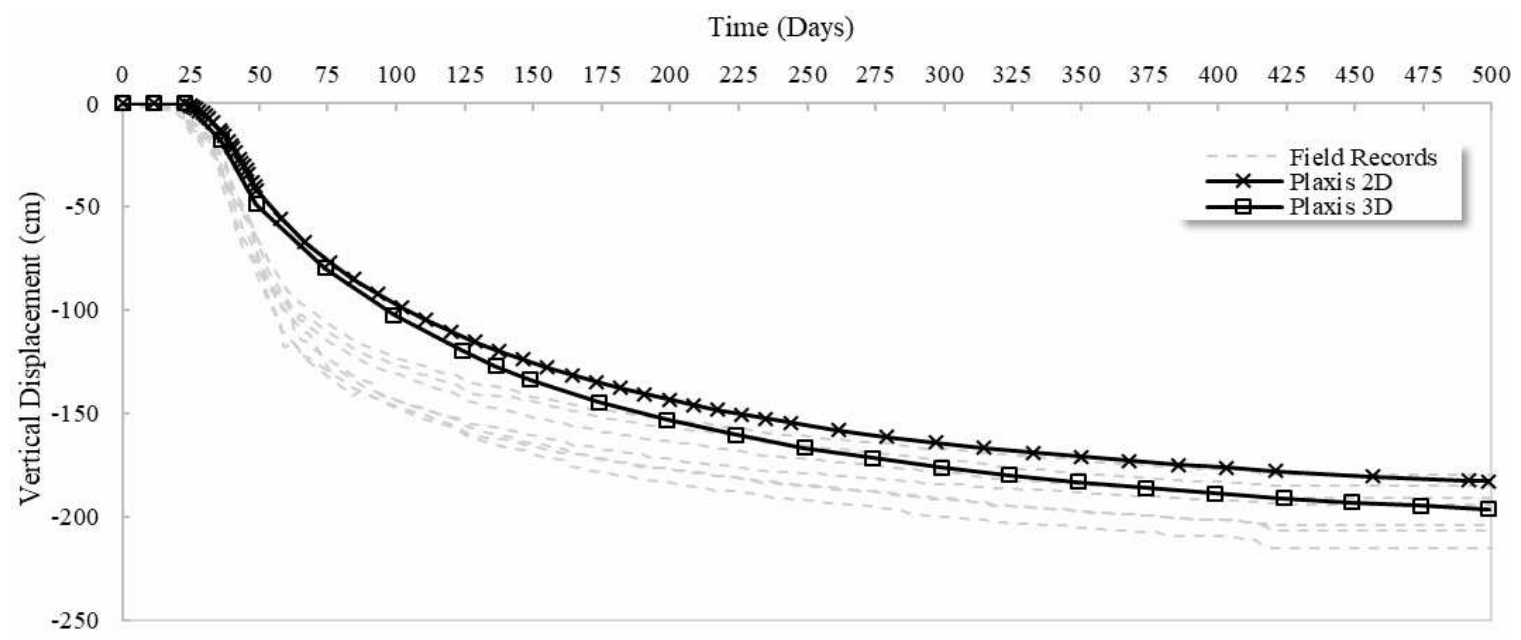

Figure 16. Field measurements for vertical displacement and numerical analysis results variation with time

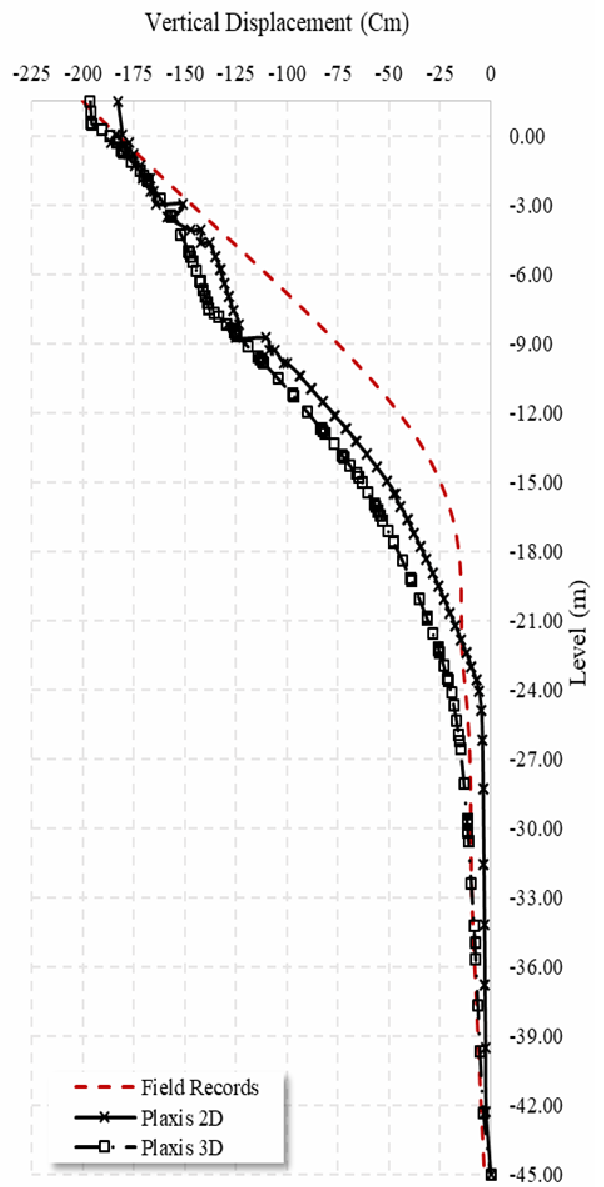

(a) Vertical displacement of Embankment Center

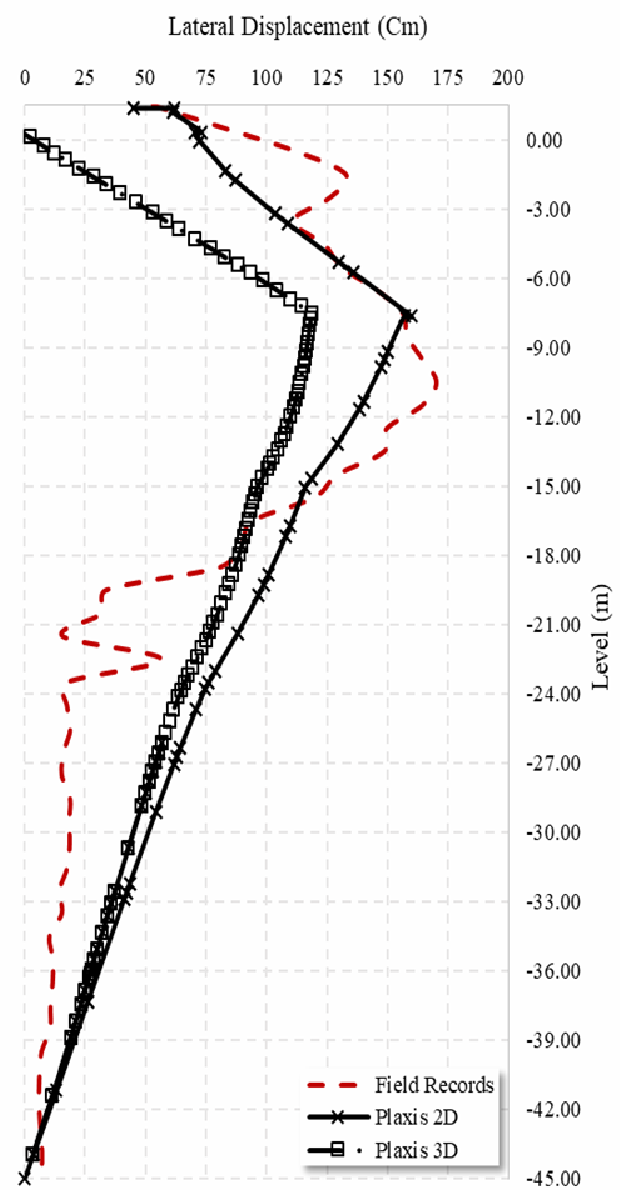

(b) Lateral displacement of Embankment toe

Figure 17. Field measurements for vertical and lateral displacements and numerical analysis results variation with level

\section{Conclusions}

The present study investigated 2D and 3D FE analysis and were compared to in-situ measurements for the performance of preloading system with partially penetrating vertical drains in consolidating marine clay deposits. The conclusions of the conducted study can be summarized in the following points: 
- FE analysis properly predicted the in-situ measurements in terms of vertical and lateral displacements. The average ratios of 3D and 2D FE to in-situ vertical displacement were about 1.03 and 0.95 respectively. For lateral displacement, these average ratios were about 0.94 and 1.2 respectively.

- Using soft soil model in the conducted study provided an adequate simulation for the behavior of marine soft clay under loading.

- In 2D analysis, the plane-strain analysis was proper to model preloading system with partially penetrating vertical drains considering permeability equivalence between axisymmetric and plane-strain conditions using Hird et al. (1995) formula.

- The triangular pattern in 2D plane-strain analysis was simulated with equivalent rectangular spacing considering the same drain Influence ratio (n) and provided a reasonable result.

- 2D plane-strain analysis considering the addressed assumption provided similar results compared to 3D analysis with reduced execution time.

- Permeability change index $C_{k}$ with value higher than $C_{k}=3 C_{c}$ has a minor effect on the final vertical displacement value.

\section{Nomenclature}

PVD Prefabricated vertical drains

FE Finite element

2D Two dimensional

3D Three dimensional

MC Mohr-Coulomb model

SSM Soft soil model

$C_{c} \quad$ Compression Index.

$C_{r} \quad$ Swelling Index

$\mathrm{e}_{\mathrm{o}} \quad$ Initial Void ratio

OCR Over consolidation ratio

$\mathrm{C}_{\mathrm{k}} \quad$ Permeability change index

$\mathrm{K}_{\mathrm{h}} \quad$ Coefficient of horizontal permeability

$\mathrm{K}_{\mathrm{v}} \quad$ Coefficient of vertical permeability

$\lambda^{*} \quad$ Modified compression index

$\kappa^{*} \quad$ Modified swelling index

$\mathrm{K}_{\mathrm{hp}} \quad$ Horizontal permeability of in plane-strain unit cell

$\mathrm{K}_{\mathrm{ax}} \quad$ Horizontal permeability of in axisymmetric unit cell

\section{Acknowledgement}

The authors would like to thank Keller Holding GmbH for providing the geotechnical data and the instrumentation records for the trial embankment field to carry out the research work.

\section{References}

Berry, P. L. \& Wilkinson, W. B. 1969, The radial consolidation of clay soils, Ge'otechnique, Vol. 19, No. 2, pp. 253-284. https://doi.org/10.1680/geot.1969.19.2.253

Hird, C.C., Pyrah, I.C., Russell, D. 1992, Finite element modeling of vertical drains beneath embankments on soft ground. Géotechnique, Vol. 42, No. 3, pp. 499-511. https://doi.org/10.1680/geot.1992.42.3.499

Hird, C.C., Pyrah, I.C., Russell, D., and Cinicioglu, F. 1995. Modelling the effects of vertical drains in two-dimensional finite element analyses of embankments on soft ground, Canadian Geotechnical Journal, Vol. 32, pp. 795-807. doi: 10.1139/t95-077

Houlsby G. T. and Teh C. I. 1988. Analysis of the piezocone in clay. Paper presented at the 1st International Symposium on Penetration Testing, ISOPT-1, Orlando, Vol. 2, pp. 777-783.

Indraratna, B., \& Redana, I. W. 1998, Laboratory determination of smear zone due to vertical drain installation. Journal of Geotechnical and Geoenvironmental Engineering, Vol. 124, No. 2, pp. 180-184. https://doi.org/10.1061/(ASCE)10900241(1998) 124:2(180)

Indraratna, B., Sathananthan, I., Bamunawita, C., \& Balasubramaniam, A. S. 2005, Theoretical and Numerical Perspectives and Field Observations for the Design and Performance Evaluation of Embankments Constructed on Soft Marine Clay. In Elsevier Geo-engineering Book Series (Vol. 3, pp. 51-89). Elsevier.

Indraratna, B. Chu, J. \& Rujikiatkamjorn, C. 2015. Ground Improvement Case Histories: Embankments with Special Reference to Consolidation and Other Physical Methods. Butterworth- Heinemann. 
Jamiolkowski, M., Ladd, C.C., Germaine, J.T. and Lancellotta, R. 1985. New developments in field and laboratory testing of soils, 11th International Conference on Soil Mechanics and Foundation Engineering, San Francisco, USA, Vol. 1, p. 57-153.

Lau, K.W.K. \& Cowland, J.W. 2000. Geosyntheically enhanced embankments for the Shenzhen river. Advance in Transportation and Geoenvironmental Systems Using Geosynthetics, Geotechnical Special Publication.

Mayne, P.W. 2001. Stress-Strain-Strength-Flow Parameters from Enhanced In-Situ Tests. Proceedings of the International Conference on In-Situ Measurement of Soil Properties \& Case Histories (In-Situ 2001), Bali, Indonesia, pp. $27-47$.

Mesri, G. \& Rokhsar, A. 1974. Theory of consolidation for clays. Journal of the Geotechnical Engineering Division, ASCE 100, No. 8, 889-904.

Onoue, A., Ting, N.-H., Germaine, J. T., and Whitman, R. V. 1991. Permeability of disturbed zone around vertical drains, Proceedings of the Geotechnical Engineering Congress, Boulder, Vol. 2, 879-890.

PLAXIS 2D User's Manuals 2020, Edited by Brinkgreve, R.B.J., Swolfs, W.M. and Engin, E., Plaxis BV, Delft, The Netherlands. PLAXIS $3 D$ User's Manuals 2020, Edited by Brinkgreve, R.B.J., Swolfs, W.M. and Engin, E., Plaxis BV, Delft, The Netherlands.

Sathananthan, I. 2005, Modelling of vertical drains with smear installed in soft clay, PhD thesis, Department of Civil, Mining and Environmental Engineering, University of Wollongong, Australia, 305p.

Tavenas, F., Jean, P., Leblond, P., \& Leroueil, S. 1983, The permeability of natural soft clays. Part II: Permeability characteristics. Canadian Geotechnical Journal, Vol. 20, No. 4, pp. 645-660. https://doi.org/10.1139/t83-073

Taylor D.W. 1948, Fundamentals of Soil Mechanics. New York, NY: John Wiley \& Sons Inc.

\section{Biographical notes}

Ahmed M. Abouhashem Ph.D. candidate, Helwan University, Cairo, Egypt. He received his M.Sc. in 2012 in Geotechnical engineering from Helwan University. Also, he is a certified geotechnical consultant engineer from the Egyptian Engineers Syndicate. He is currently the section head of geotechnical department in ElSewedy Electric power system projects Co.

Alaa El-Din A. El-Gendy is the former cultural advisor and director of the Egyptian educational mission office, London, England. He is currently a Professor of Soil Mechanics and Foundation Engineering, Helwan University. He has presented many research articles at national and international conferences.

Mohamed H. Rabie is currently the Dean of Faculty of Engineering, Helwan University (Mataria Branch), Cairo, Egypt. Also, he is a Professor of Soil Mechanics and Foundation Engineering, Helwan University. He has published many papers in international journals. He has also presented dozens of research articles at national and international conferences.

Mohamed A. Mostafa is an Assistant Professor of Soil Mechanics and Foundation Engineering, Helwan University, Cairo, Egypt. Also, he is a geotechnical consultant for mega projects in Egypt and worldwide. He has presented many research articles at national and international conferences. 